\title{
ANALISIS PUSHOVER TERHADAP KETIDAKBERATURAN STRUKTUR GEDUNG UNIVERSITAS 9 LANTAI
}

\section{(Pushover analysis for Irregular Building Structures: Case study university buildings 9 floor)}

\author{
Yulinda Timur Laresi ${ }^{1}$, Mohammad Ihsan ${ }^{1}$, Sofia W. Alisjahbana ${ }^{1}$ \\ ${ }^{1}$ Program Studi Teknik Sipil Universitas Bakrie \\ E-mail: yulindatimur@gmail.com
}

\begin{abstract}
ABSTRAK
Indonesia merupakan wilayah yang rawan terjadi gempa. Gempa bumi yang diakibatkan oleh pergerakan lempeng bumi merupakan penyebab terbesar dari gempa yang akan menimbulkan kerusakan pada struktur gedung. Gempa bumi yang terjadi di Indonesia sering kali memakan korban jiwa. Namun, dapat dipastikan bahwa penyebab adanya korban jiwa bukan diakibatkan secara langsung oleh gempa, tetapi diakibatkan oleh rusaknya bangunan yang menyebabkan keruntuhan pada bangunan tersebut.Tujuan penulisan tugas akhir adalah menentukan kriteria kinerja seismik struktur gedung universitas dari hasil nilai performance point menggunakan code ATC-40, memperlihatkan skema kelelehan (distribusi sendi plastis) yang terjadi dari hasil perhitungan program software, mengetahui pola keruntuhan bangunan sehingga dapat diketahui joint-joint yang mengalami kerusakan dan mengalami kehancuran serta membandingkan hasil dari analisis respon spektra dengan analisis pushover.
\end{abstract}

Dari hasil penelitian, Struktur bangunan mampu memberikan perilaku nonlinear yang ditunjukkan fase awal dan mayoritas terjadinya sendi-sendi plastis terjadi pada elemen balok baru kemudian elemen kolom. Level kinerja struktur masuk kriteria Immediate Occupancy yang berarti terjadi kerusakan kecil pada struktural dan bangunan dapat segera digunakan kembali.

Kata Kunci: Pushover, Nonlinear, Sendi Plastis

\begin{abstract}
Indonesia is an area prone to earthquakes. Earthquakes caused by the movement of the earth's plates are the biggest cause of earthquakes that will cause damage to the building structure. Earthquakes occurring in Indonesia often cost lives. However, it is certain that the cause of the loss of life is not directly caused by the earthquake, but caused by the destruction of the building that caused the collapse in the building. The purpose of writing the final task is to determine the performance criteria of the university building's seismic performance from the performance point value using the ATC-40 code, showing the melamine scheme (plastic joint distribution) occurring from the calculation of the software program, knowing the collapse pattern of the building so it can be known the joints Suffered damage and suffered destruction and compared the results of spectral response analysis with pushover analysis. From the results of the study, the structure of the building is able to provide nonlinear behavior indicated by the initial phase and the majority of plastic joints occur in new beam elements and then column elements. The performance level of the structure enters the criterion of Immediate Occupancy which means that minor structural and building damage can be reused immediately.
\end{abstract}

Keywords:Pushover, Nonlinear, Plastic Joints 


\section{PENDAHULUAN}

Indonesia merupakan wilayah yang berada pada jalur gempa pasifik dan jalur gempa asia. Hal ini menyebabkan Indonesia sering mengalami gempa bumi. Gempa bumi yang diakibatkan oleh pergerakan lempeng bumi merupakan penyebab terbesar dari gempa yang akan menimbulkan kerusakan pada struktur gedung. Gempa bumi didefinisikan sebagai getaran yang bersifat alamiah, yangterjadi pada lokasi tertentu, dan sifatnya tidak berkelanjutan. Gempa bumi yang terjadi di Indonesia sering kali memakan korban jiwa. Namun, dapat dipastikan bahwa penyebab adanya korban jiwa bukan diakibatkan secara langsung oleh gempa, tetapi diakibatkan oleh rusaknya bangunan yang menyebabkan keruntuhan pada bangunan tersebut dan berakibat adanya korban jiwa.

Hal yang terjadi tersebut diminimalisir dengan membuat suatu struktur bangunan tahan gempa. Yaitu bangunan yang ketika terjadi gempa tidak mengalami kerusakan yang berat pada strukturnya ataupun apabila struktur bangunan mengalami keruntuhan, mampu menunjukkan perilaku nonlinear pada kondisi pasca-elastic, sehingga lebih terjamin tingkat keamanannya pada bangunan terhadap gempa serta meminimalisir adanya korban jiwa. Desain struktur bangunan tahan gempa harus berdasarkan kriteria serta peraturan-peraturan yang berlaku. Struktur bangunan tahan gempa didesain menggunakan metode analisis pushover.

Tugas akhir ini dilakukan menggunakan model struktur bangunan gedung universitas lantai menggunakan struktur rangka beton bertulang dan berfungsi sebagai sarana pendidikan dengan kondisi tanah dibawah bangunan adalah tanah lunak. Jenis system rangka pemikul momen yang digunakan adalah SRPMK (Sistem Rangka Pemikul Momen Khusus). Didesain sesuai Standar Perencanaan Ketahanan Gempa untuk Bangunan Gedung (SNI 1726:2012) dan Tata Cara Perhitungan Struktur Beton untuk Bangunan Gedung (SNI 2847:2013).

\section{TINJAUAN PUSTAKA}

\section{Konsep Dasar Mekanisme Gempa Bumi}

Gempa bumi adalah pelepasan energi pada muka bumi, merambat melalui permukaan tanah. Terjadinya gempa bumi disebabkan oleh benturan/gesekan antara plat tektonik (lempeng bumi) atau amblesnya dasar laut. Lempeng samudera yang rapat massanya lebih besar bertumbukkan dengan lempeng benua di zona tumbukan (subduksi) akan menyusup ke bawah. Gerakan lempeng itu akan mengalami perlambatan akibat gesekan dari selubung bumi. Perlambatan gerak itu menyebabkan penumpukkan energi di zona subduksi dan zona patahan. Akibatnya zona-zona itu terjadi tekanan, tarikan dan geseran. Pada batas elastisitas lempeng terlampaui maka terjadilah patahan batuan yang diikuti oleh lepasnya energi secara tiba-tiba. Proses ini menimbulkan getaran partikel ke segala arah yang disebut gelombang gempa.

\section{Ketentuan Umum Bangunan Gedung Tahan Gempa}

\section{Faktor Keutamaan dan Kategori Risiko Struktur Bangunan}

Tabel 1. Kategori Risiko Bangunan Gedung Dan Non Gedung Untuk Beban Gempa

\begin{tabular}{|c|c|c|}
\hline No & Jenis Pemanfaatan & $\begin{array}{c}\text { Kategori } \\
\text { Risiko }\end{array}$ \\
\hline 1 & $\begin{array}{l}\text { Gedung dan non gedung yang memiliki risiko rendah } \\
\text { erhadap jiwa manusia pada saat terjadi kegagalan, } \\
\text { ermasuk, tapi tidak dibatasi Antara lain: } \\
\text { Fasilitas pertanian, perkebunan, peternakan, dan } \\
\text { perikanan } \\
\text { Fasilitas sementara } \\
\text { Gudang penyimpanan } \\
\text { Rumah jaga dan struktur kecil lainnya }\end{array}$ & I \\
\hline 2 & $\begin{array}{l}\text { Semua gedung dan struktur lain, kecuali yang } \\
\text { ermasuk dalam kategori risiko I, III, IV, termasuk, tapi } \\
\text { idak dibatasi untuk: } \\
\text { Perumahan } \\
\text { Rumah Toko dan Rumah Kantor } \\
\text { Pasar } \\
\text { - Gedung Perkantoran } \\
\text { Gedung Apartemen/Rumah Susun } \\
\text { Pusat Perbelanjaan/Mall } \\
\text { Bangunan Industri } \\
\text { Fasilitas Manufaktur }\end{array}$ & II \\
\hline 3 & $\begin{array}{l}\text { Gedung dan non gedung yang memiliki risiko tinggi } \\
\text { erhadap jiwa manusia pada saat terjadi kegagalan, } \\
\text { ermasuk, tapi tidak dibatasi untuk: } \\
\text { - Bioskop } \\
\text { - Gedung pertemuan } \\
\text { Stadion } \\
\text { Fasilitas kesehatan yang tidak memiliki unit bedah } \\
\text { dan unit gawat darurat } \\
\text { Fasilitas Penitipan Anak } \\
\text { Penjara } \\
\text { Bangunan Untuk orang jompo }\end{array}$ & III \\
\hline 4 & $\begin{array}{l}\text { Gedung dan non gedung, tidak termasuk dalam } \\
\text { kategori risiko IV, yang memiliki potensi untuk } \\
\text { menyebabkan dampak ekonomi yang besar dan/atau } \\
\text { gangguan massal terhadap kehidupan masyarakat } \\
\text { sehari-hari bila terjadi kegagalan, termasuk, tapi tidak } \\
\text { dibatasi untuk } \\
\text { Pusat pembangkit listrik biasa } \\
\text { Fasilitas penanganan air } \\
\text { Fasiltias penanganan limbah } \\
\text { Fusat telekomunikasi } \\
\text { Gedung dan non gedung yang tidak termasuk dalam } \\
\text { isiko IV, (termasuk, tapi tidak dibatasi untuk fasilitas } \\
\text { manufaktur, proses, penanganan, penyimpanan, } \\
\text { penggunaan atau tempat pembuangan bahan bakar } \\
\text { perbahaya, bahan kimia berbahaya limbah berbahaya, } \\
\text { atau bahan yang mudah meledak) yang mengandung } \\
\text { pahan beracun atau bahan peledak dimana jumlah } \\
\text { kandungan bahannya melebihi nilai batas yang } \\
\text { diisyaratjan oleh instansi yang berwenang dan cukup } \\
\text { menimbulkan bahaya bagi masyarakat jika terjadi } \\
\text { kebocoran. }\end{array}$ & III \\
\hline 5 & $\begin{array}{l}\text { Gedung dan non gedung yang ditunjukan sebagai } \\
\text { asilitas yang penting,termasuk, tapi tidak dibatasi } \\
\text { untuk: } \\
\text { Bangunan-bangunan monumental } \\
\text { Gedung sekolah dan fasilitas pendidikan } \\
\text { Rumah sakit dan fasilitas kesehatan lainnya yang } \\
\text { memiliki fasilitas bedah dan unit gawat darurat } \\
\text { Fasilitas pemadam kebakaran, ambulans, dan kantor } \\
\text { polisi, serta garasi kendaraan darurat } \\
\text { Tempat perlindungan terhadap gempa bumi, angina } \\
\text { badai dan tempat perlindungan darurat lainnya } \\
\text { Fasilitas kesiapan darurat komunikasi, pusat operasi, } \\
\text { dan fasilitas lainnya untuk tanggap darurat } \\
\text { Pusat pembangkit energi dan fasilitas publik lainnya } \\
\text { yang dibutuhkan pada saat darurat } \\
\text { Struktur tambahan (Termasuk menara } \\
\text { telekomunikasi, Tangki penyimpanan, bahan } \\
\text { bakar, menara pendingin, struktur stasiun listrik, } \\
\text { tangki air pemadam kebakaran atau struktur } \\
\text { rumah atau struktur pendukung air atau material } \\
\text { atau peralatan pemadam kebakaran) yang } \\
\text { diisyaratkan untuk beroperasi pada saat keadaan } \\
\text { darurat. }\end{array}$ & IV \\
\hline
\end{tabular}




\begin{tabular}{|c|c|c|}
\hline No & \multicolumn{1}{|c|}{ Jenis Pemanfaatan } & $\begin{array}{c}\text { Kategori } \\
\text { Risiko }\end{array}$ \\
\hline & $\begin{array}{l}\text { Gedung dan non gedung yang dibutuhkan untuk } \\
\text { mempertahankan fungsi struktur bangunan lain yang } \\
\text { masuk kedalam kategori risiko IV }\end{array}$ & \\
\hline & \multicolumn{1}{|}{,} & \\
\hline
\end{tabular}

Sumber : Tata cara perencanaan ketahanan gempa untuk struktur bangunan gedung dan non gedung (Standar Nasional Indonesia 1726:2012. hal.15)

\section{Wilayah Gempa dan Spektrum Respon}

Parameter Ss (percepatan batuan dasar pada perioda pendek) dan S1 (percepatan batuan dasar pada perioda 1 detik) harus ditetapkan masing-masing dari respons spektral percepatan 0,2 detik dan 1 detik dalam peta gerak tanah seismik pada dengan kemungkinan 2 persen terlampaui dalam 50 tahun (MCER, 2 persen dalam 50 tahun), dan dinyatakan dalam bilangan desimal terhadap percepatan gravitasi. Bila S1 0,04 g dan Ss 0,15 g, maka struktur bangunan boleh dimasukkan ke dalam kategori desain seismik $A$, dan cukup memenuhi persyaratan.

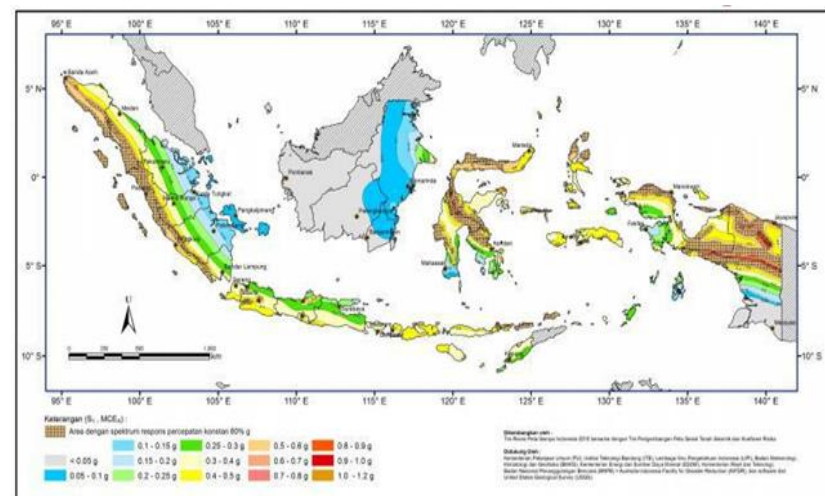

Gambar 1.S1, Gempa maksimum yang dipertimbangkan risiko-tertarget (MCER), kelas situs SB Sumber : Tata cara perencanaan ketahanan gempa untuk struktur bangunan gedung dan non gedung (Standar Nasional Indonesia 1726:2012.)

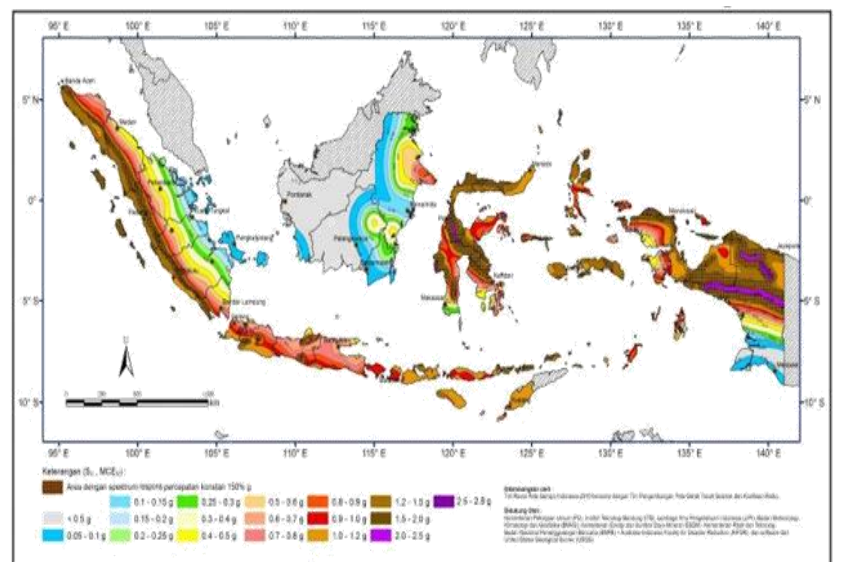

Gambar 2. SS, Gempa maksimum yang dipertimbangkan risiko-tertarget (MCER), kelas situs SB

Sumber : Tata cara perencanaan ketahanan gempa untuk struktur bangunan gedung dan non

gedung (Standar Nasional Indonesia 1726:2012.)
Untuk penentuan respons spektral percepatan gempa MCER di permukaan tanah, diperlukan suatu faktor amplifikasi seismik pada perioda 0,2 detik dan perioda 1 detik. Faktor amplifikasi meliputi faktor amplifikasi getaran terkait percepatan pada getaran perioda pendek Fa dan faktor amplifikasi terkait percepatan yang mewakili getaran perioda 1 detik Fv. Parameter spektrum respons percepatan pada perioda pendek SMS dan perioda 1 detik SM1 yang disesuaikan dengan pengaruh klasifikasi situs, harus ditentukan dengan perumusan berikut ini:

$\mathrm{S}_{\mathrm{MS}}=\mathrm{Fa}$.Ss

$\mathrm{S}_{\mathrm{M} 1}=\mathrm{F}_{\mathrm{V}} \cdot \mathrm{S} 1$

\section{Keterangan}

$\mathrm{S}_{\mathrm{s}}=$ parameter respons spektral percepatan gempa $M C E_{r}$ terpetakan untuk perioda pendek $S_{1}=$ parameter respons spektral percepatan gempa $\mathrm{MCE}_{\mathrm{r}}$ terpetakan untuk perioda 1,0 detik dan koefisien situs Fa dan Fv mengikuti Tabel 2. dan Tabel 3.

Tabel 2. MCER untuk $T=0.2$ detik

\begin{tabular}{|c|c|c|c|c|c|}
\hline $\begin{array}{c}\text { Kelas } \\
\text { situs }\end{array}$ & \multicolumn{5}{|c|}{$\begin{array}{r}\text { Parameter respons spektral percepatan gempa (MCER) } \\
\text { terpetakan pada perioda pendek, T=0,2 detik, Ss }\end{array}$} \\
\hline & Ss =2,5 & Ss = 0,5 & Ss = 0,75 & Ss = 1,0 & Ss = 1,25 \\
\hline SA & 0,8 & 0,8 & 0,8 & 0,8 & 0,8 \\
\hline SB & 1,0 & 1,0 & 1,0 & 1,0 & 1,0 \\
\hline SC & 1,2 & 1,2 & 1,1 & 1,0 & 1,0 \\
\hline SD & 1,6 & 1,4 & 1,2 & 1,1 & 1,0 \\
\hline SE & 2,5 & 1,7 & 1,2 & 0,9 & 0,9 \\
\hline SF & & & $S S^{b}$ & & \\
\hline
\end{tabular}

${ }^{*}$ catatan:

a.) Untuk nilai-nilai antara Ss dapat dilakukan interpolasi linier

b.) $\mathrm{SS}=$ Situs yang memerlukan investigasi geoteknik spesifik dan analisis respons situs spesifik

Tabel 3. MCER untuk $\mathrm{T}=1$ detik

\begin{tabular}{|c|c|c|c|c|c|}
\hline $\begin{array}{c}\text { Kelas } \\
\text { situs }\end{array}$ & \multicolumn{5}{|c|}{$\begin{array}{c}\text { Parameter respons spektral percepatan gempa (MCER) } \\
\text { terpetakan pada perioda 1 detik, S1 }\end{array}$} \\
\hline & $\mathrm{S}_{1} 0,1$ & $\mathrm{~S}_{1}=0,2$ & $\mathrm{~S}_{1}=0,2$ & $\mathrm{~S}_{1}=0,4$ & $\mathrm{~S}_{1} 0,5$ \\
\hline SA & 0,8 & 0,8 & 0,8 & 0,8 & 0,8 \\
\hline SB & 1,0 & 1,0 & 1,0 & 1,0 & 1,0 \\
\hline SC & 1,7 & 1,6 & 1,5 & 1,4 & 1,3 \\
\hline SD & 2,4 & 2 & 1,8 & 1,6 & 1,5 \\
\hline SE & 3,5 & 3,2 & 2,8 & 2,4 & 2,4 \\
\hline SF & & & SS ${ }^{b}$ & \\
\hline
\end{tabular}

Sumber : Tata cara perencanaan ketahanan gempa untuk struktur bangunan gedung dan non gedung (Standar Nasional Indonesia 1726:2012.) 


\section{Parameter Percepatan Spektral Desain}

Parameter percepatan spektral desain untuk perioda pendek, $S_{D S}$ dan pada perioda 1 detik, $S_{D 1}$ harus ditentukan melalui perumusan berikut ini:

$S_{D S}=\frac{2}{3} S_{\mathrm{MS}}$

$S_{D I}=\frac{2}{3} S_{\mathrm{M} 1}$

Jika digunakan prosedur desain yang disederhanakan, maka nilai SDS harus ditentukan dan nilai SD1 tidak perlu ditentukan.

\section{Kategori Desain Seismik}

Struktur harus ditetapkan memiliki suatu kategori desain seismik yang mengikuti pasal ini. Struktur dengan kategori risiko I, II, atau III yang berlokasi di mana parameter respons spektral percepatan terpetakan pada perioda 1 detik, S1, lebih besar dari atau sama dengan 0,75 harus ditetapkan sebagai struktur dengan kategori desain seismik E. Struktur yang berkategori risiko IV yang berlokasi di mana parameter respons spektral percepatan terpetakan pada perioda 1 detik, S1, lebih besar dari atau sama dengan 0,75 , harus ditetapkan sebagai struktur dengan kategori desain seismik F. Semua struktur lainnya harus ditetapkan kategori desain seismik-nya berdasarkan kategori risikonya dan parameter respons spektral percepatan desainnya, SDS dan SD1. Masing-masing bangunan dan struktur harus ditetapkan ke dalam kategori desain seismik yang lebih parah, dengan mengacu pada Tabel 4 atau 1, terlepas dari nilai perioda fundamental getaran struktur, T.

Tabel 4. Kategori desain seismik berdasarkan parameter respons percepatan pada perioda pendek

\begin{tabular}{|l|l|l|}
\hline Nilai SDS & Kategori risiko \\
\hline & I atau II atau III & IV \\
\hline SDS $<0,167$ & A & A \\
\hline 0,167 SDS & B & C \\
0,33 & & \\
\hline 0,33 SDS 0,50 & C & D \\
\hline 0,50 SDS & D & D \\
\hline
\end{tabular}

Tabel 5. Kategori desain seismik berdasarkan parameter respons percepatan pada perioda 1 detik

\begin{tabular}{|l|l|l|}
\hline Nilai SD1 & Kategori risiko \\
\hline & I atau II atau III & IV \\
\hline SD1 $<0,167$ & A & A \\
\hline $\begin{array}{l}0,067 \text { SD1 } \\
0,133\end{array}$ & B & C \\
\hline 0,133 SD1 0,20 & C & D \\
\hline 0,20 SD1 & D & D \\
\hline
\end{tabular}

\section{Penelitian Terdahulu}

1. Nama: Ary Marwanto, Agus Setiya Budi, dan Agus Supriyadi (Jurnal Tahun 2014)

Judul: Evaluasi Kinerja Struktur Gedung 10 Lantai dengan Analisis Pushover Terhadap Drift Dan
Displacement Menggunakan Software Etabs (Studi Kasus : Hotel Di Wilayah Surakarta)

Kesimpulan:

Penelitian ini menggunakan analisis nonlinier pushover dengan program ETABS. Metode penelitian diawali dengan pemodelan struktur 3 dimensi dengan menggunakan software ETABS sesuai shopdrawing. Setelah pemodelan dilakukan analisis perhitungan pembebanan pada struktur tersebut berupa beban mati, beban hidup dan beban tambahan. Pada static pushover case dibuat dua macam pembebanan, dimana yang pertama adalah pembebanan akibat beban gravitasi. Dan pola yang kedua memberi beban secara berangsur-angsur adalah sesuai dengan mode pertama struktur. Hasil pushover disimpan secara multiple statis dengan jumlah minimum 5 steps dan maksimum 1001 steps. Hasil analisis diperoleh nilai drift pada arah $\mathrm{x}$ adalah 0,00312 dan pada arah y adalah 0,00298 . Nilai maksimal in-elastic drift pada arah $\mathrm{x}$ adalah 0,00310 dan arah y adalah 0,00297. Menurut ATC-40, nilai level kinerja termasuk Immediate Occupancy.

2. Nama : Nissa Zahra Rachman, Edy Purwanto dan Agus Suptiyadi (Jurnal tahun 2012)

Judul: Analisis Kinerja Struktur Pada Gedung Bertingkat Dengan Analisis Pushover Menggunakan Software Etabs (Studi Kasus: Bangunan Hotel Di Semarang)

Kesimpulan:

Penelitian ini bertujuan untuk mengetahui kinerja gedung berdasarkan mekanisme terbentuknya sendi plastis pada balok kolom serta hubungan base shear dengan displacement pada kurva pushover dan kurva seismic demand. Metode yang digunakan adalah analisis statik nonlinier pushover dengan menggunakan program ETABS. Kesimpulan dari penelitian menunjukkan bahwa gaya geser dari evaluasi pushover pada arah $\mathrm{x}$ sebesar 557,867 ton. Nilai displacement adalah 0,112 m. Displacement pada gedung tidak melampaui displacement yang dijinkan, sehingga gedung aman terhadap gempa rencana. Maksimum total drift adalah $0,0035 \mathrm{~m}$ dan maksimum Inelastic drift adalah 0,0034 m, Sehingga gedung termasuk dalam level kinerja Immediate Occupancy (IO).

3. Nama: Wibowo, Edy Purwanto dan Dwi Yanto (Jurnal Tahun 2010)

Judul : Menentukan Level Kinerja Struktur Beton Bertulang Pasca Gempa

Kesimpulan:

Tujuan dari kajian ini adalah untuk menjawab secara ilmiah permasalahan tentang tingkat keamanan struktur gedung beton bertulang pasca serangan gempa (kasus gempa Jogja pada tahun 2006). Metode yang digunakan adalah dengan observasi langsung dilapangan, mengumpulkan data perencanaan, data asbuilt drawing, membuat model struktur dan melakukan analisis pushover. Sampel yang digunakan adalah sebuah gedung perkantoran di wilayah kota Surakarta. Hasil kajian menunjukkan bahwa secara struktural, gedung yang menjadi sampel kajian, masuk kategori Immediate Ocupancy (IO) yang berarti belum 
terjadi kerusakan struktur yang berarti akibat gempa terjadi, namun harus dilakukan perbaikan terhadap beberapa kerusakan agar tidak menjadi kerusakan lebih besar akibat gaya gravitasi dan beban layan gedung.

4. Nama: Hizkia Yehezkiel Mamesah, Steenie E. Wallah \& Reky Stenly Windah (Jurnal Tahun 2014) Judul : Analisis Pushover Pada Bangunan dengan Soft First Story

Kesimpulan:

Dari hasil analisis dan pembahasan terhadap 3 tipe bangunan yaitu bangunan Non Soft Story, Soft First Story 1, Soft First Story 2, dapat ditarik kesimpulan sebagai berikut :

- Gaya geser maksimum terjadi pada gedung Non Soft Story yaitu sebesar 2.334 ton. Gaya geser terkecil terjadi pada gedung Soft First Story 2 yaitu sebesar 1.359 ton. Sedangkan simpangan maksimum terjadi pada gedung Non Soft Story yaitu sebesar $0,34 \mathrm{~m}$ dan yang paling kecil pada gedung Soft First Story 2 yaitu sebesar 0,26 m.

- Simpangan maksimum yang terjadi sebelum keruntuhan pada setiap bangunan memenuhi syarat yang diberlakukan oleh SNI 1726-2012

- Level kinerja struktur berdasarkan target perpindahan dari metode Koefisien Perpindahan FEMA-356 menunjukkan bahwa pada ketiga model bangunan tersebut berada pada level Damage Control dimana kondisi gedung belum mengalami kerusakan berarti dan dapat difungsikan kembali.

- Level kinerja struktur berdasarkan target perpindahan dari metode Spektrum Kapasitas ATC-40 menunjukkan bahwa ketiga model bangunan tersebut berada pada level Immediate Occupancy dimana kondisi gedung hampir sama dengan kondisi sebelum gempa dan dapat digunakan kembali.

- Distribusi sendi plastis sesuai yang diharapkan, yaitu sesuai dengan sistem kolom kuat balok lemah, karena terjadi keruntuhan pada balok dulu kemudian diikuti pada kolom.

5. Nama: Adrian Fredrick C. Dya \& Andres Winston C. Oretaa(Jurnal Tahun 2015)

Judul : Seismic Vulnerability Assessment Of Soft Story Irregular Buildings Using Pushover Analysis

Kesimpulan:

Setelah analisis hasil pemodelan untuk bangunan soft story, dapat dilihat bahwa penyebab utama bangunan soft story lebih rentan terhadap gempa bumi adalah lokalisasi kekuatan seismik. Meskipun total permintaan pada bangunan lebih kecil karena tinggi bangunan yang berbeda, permintaan yang tidak merata pada area bangunan menyebabkan bahaya lokal. Kekuatan terkonsentrasi pada segmen bangunan dimana ada pengurangan kekakuan yang berada di lokasi soft story. Hal ini dapat diamati melalui pengembangan plastic hinges, story drift bangunan, serta disain. Parameter seismik ini menunjukkan lokalisasi permintaan seismik.

Risiko bangunan meningkat karena meningkatnya bahaya pada area tertentu. Kenaikan risiko juga tergantung pada jumlah atau tingkat keparahan soft story bangunan dan dengan demikian pengubah ketidakteraturan soft story dikategorikan lebih lanjut untuk mempertimbangkan tingkat keparahannya.

Diketahui bahwa setiap bangunan yang dirancang dengan benar akan mampu menahan eksitasi seismik tanpa menimbulkan kerusakan yang cukup besar. Perancang bangunan struktural harus memperhatikan dengan seksama daerah ini saat merancang bangunan soft story.

\section{METODOLOGI}

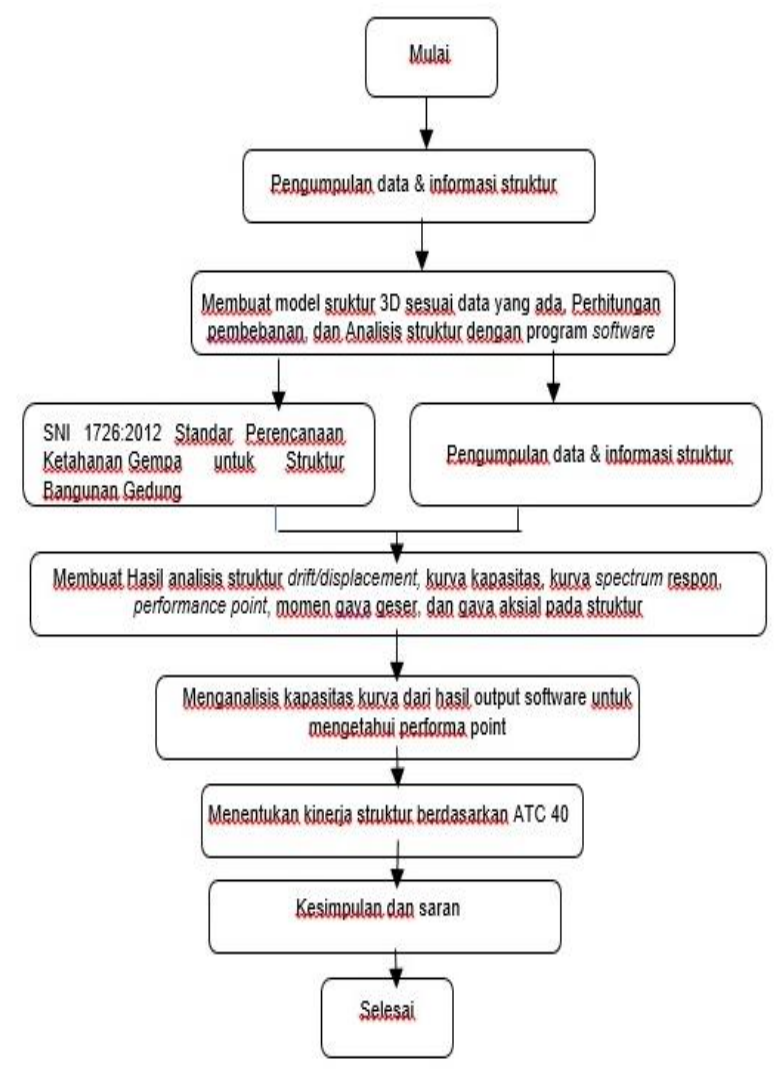

Gambar 3. Diagram alir penelitian

\section{HASIL DAN PEMBAHASAN}

\section{Spektrum Respons dan Desain}

Berdasarkan SNI 1726:2012, spektrum respons gempa rencana desain harus dihitung terlebih dahulu. Adapun perhitungannya dilakukan dengan langkahlangkah sebagai berikut:

1. Menentukan kategori pemanfaatan (Occupancy Category) bangunan berdasarkan tabel untuk jenis pemanfaatan bangunan. Struktur gedung universitas yang direncanakan ini termasuk ke dalam ketegori gedung dan fasilitas pendidikan memiliki kategori pemanfaatan IV.

2. Menentukan faktor keutamaan (Importance Factors) bangunan Berdasarkan tabel untuk occupancy category IV maka diperoleh faktor keutamaan gempa, le $=1,50$.

3. Jakarta merupakan daerah yang mayoritas memiliki jenih tanah yang berupa tanah lunak. 
Selain itu hasil penyelidikan tanah pada lokasi struktur bangunan yang akan dibangun juga memiliki kriteria yang sama dengan peraturan SNI 1726:2012 yang menunjukkan bahwa klasifikasi kelas situs pada proyek gedung 9 lantai yaitu SE (tanah lunak).

4. Menentukan besarnya parameter percepatan spektral desain untuk perioda pendek (SDS) dan pada perioda 1 detik (SD1). Nilai SDS dan SD1 diperoleh berdasarkan peta gempa Indonesia. Seperti yang tercantum dalam peraturan SNI bahwa nilai SDS dan SD1 tergantung pada dimana lokasi bangunan tersebut dibangun. Berikut nilai SS (parameter respons spektral percepatan gempa MCER terpetakan untuk perioda pendek) dan S1 (parameter respons spektral percepatan gempa MCER terpetakan untuk perioda 1,0 detik) yang terdapat pada laporan Site Specific Response Spectrum. Berdasarkan laporan yang ada, untuk daerah Jakarta didapatkan besarnya nilai SS = 0.6-0.7 g dan $S 1=0.25-0.3 \mathrm{~g}$. Berdasarkan peta zonasi gempa untuk kota Jakarta diperoleh: $\mathrm{SS}=$ $0,68 \mathrm{~g}, \mathrm{~S} 1=0,29 \mathrm{~g}$

5. Menentukan koefisien situs (site coefficient) Fa dan Fv. Berdasarkan SNI 1726:2012 Pasal 6.3 hal.22 dengan $S S=0,68$ untuk site class $E$ didapatkanlah besar koefisien situs, $\mathrm{Fa}=1,34$ Berdasarkan SNI 1726:2012 Pasal 6.3 hal.22 dengan $S 1=0,29$ untuk site class $\mathrm{E}$ didapatkanlah besar koefisien situs, $\mathrm{FV}=2,84$

6. Berdasarkan SNI 1726-2012 Pasal 6.3 hal.23 Menentukan Maximum Considered Earthquake (MCE) Spectral Respons Acceleration pada perioda SDS $=2 / 3(\mathrm{Fa} . \mathrm{SS})=2 / 3(1,34 \times 0.68)=$ $0.607 \mathrm{~g}$

7. Menentukan Maximum Considered Earthquake (MCE) Spectral Respons Acceleration pada perioda 1,0 detik, SD1. SD1 $=2 / 3($ Fv.S1 $)=2 / 3$ $(2,84 \times 0,29)=0.549 \mathrm{~g}$

8. Berdasarkan SNI 1726:2012 Pasal 6.5 hal. 24-35 Tabel 6 \& 7, menentukan Kategori Desain SeismikKDS (Seismic Design Category-SDC). Pada site class $\mathrm{E}$ dengan $\mathrm{SDS}=0.607 \mathrm{~g}$ dan $\mathrm{SD} 1=0.549 \mathrm{~g}$ diperoleh Kategori Desain Seismic-KDS (Seismic Design Category-SDC) adalah D (resiko gempa tinggi/ high seismic risk).

9. Menentukan Nilai To dan Ts

$\mathrm{Ts}=\mathrm{SD} 1 / \mathrm{SDS}=0.549 / 0.607=0,904$

$\mathrm{T} 0=0.2(\mathrm{SD} 1 / \mathrm{SDS})=0.2(0.549 / 0.607)=0.1808$

10. Menentukan nilai $\mathrm{Sa}$

a. Untuk periode ulang lebih kecil dari To, spectrum respns percepatan desain, Sa harus diambil dari persamaan :

$$
S_{a}=S_{D S}\left(0,4+0,6 \frac{T}{T_{0}}\right)
$$

b. Untuk periode yang lebih besar dari atau sama dengan To dan lebih kecil dari atau sama dengan Ts, spectrum respons desain, Sa, sama dengan SDS.

c. Untuk periode yang lebih besar dari Ts, spectrum respons desain, Sa, diambil berdasarkan persamaan:
Adapun grafik spektrum respons gempa desain untuk wilayah gempa Jakarta adalah sebagai berikut:

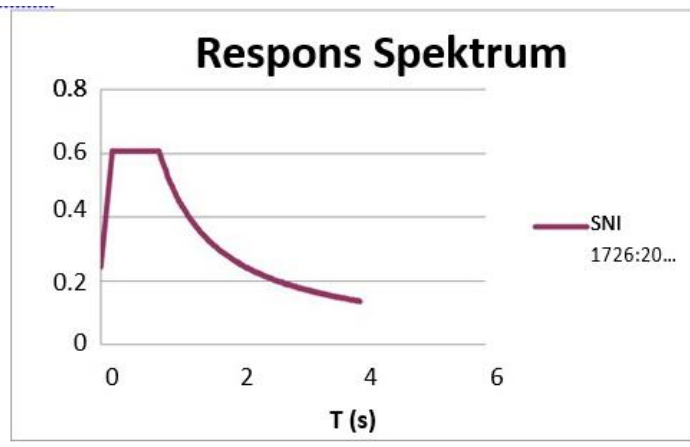

Gambar 4. Grafik respon spectrüm desain gempa wilayah Jakarta

d. Faktor reduksi gempa diambil dari tabel nilai $\mathrm{R}=$ $8, \Omega 0=3$ dan $\mathrm{Cd}=5,5 \mathrm{SNI} 1726-2012$, nilai faktor reduksi gempa dengan jenis sistem rangka penahan momen dengan rangka momen beton bertulang khusus adalah 8

\section{Aproksimasi Periode Fundamental}

T yang digunakan arah $\mathrm{x}$ adalah

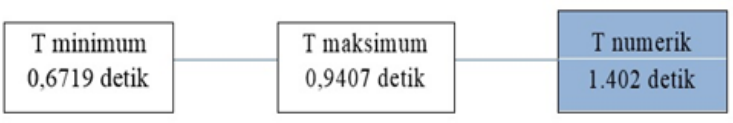

Gambar 5. T minimum, T maksimum, dan T numerik

Nilai T yang digunakan adalah 0,9407 detik karena nilai T numerik melebihi batasan T maksimum.

Dengan demikian $T$ yang digunakan untuk arah $Y$ adalah:

Tabel 6. Perhitungan distribusi vertical gaya gempa dan distribusi horizontal gempa arah $\mathrm{X}$

\begin{tabular}{|c|c|c|c|c|c|}
\hline \multicolumn{6}{|c|}{ EQUIVALENT LATERAL FORCE (STATIC ANALYSIS) } \\
\hline \multirow{2}{*}{ No. } & \multirow{2}{*}{ Story } & $\begin{array}{c}\text { Story } \\
\text { Weight, } \\
\text { Wi }\end{array}$ & WiHik & Fy Static & $\begin{array}{c}\text { VSTATIC } \\
\text { (VELF) }\end{array}$ \\
\cline { 3 - 6 } & & [tonf] & [tonf] & & [tonf] \\
\hline 1 & STORYROOF & 1853.369 & 296198.586 & 397.287 & 397.287 \\
\hline 2 & STORY8 & 3006.590 & 406345.164 & 545.025 & 942.312 \\
\hline 3 & STORY7 & 3622.273 & 405023.858 & 543.253 & 1485.564 \\
\hline 4 & STORY6 & 5820.584 & 523302.622 & 701.898 & 2187.462 \\
\hline 5 & STORY5 & 5567.823 & 387225.437 & 519.380 & 2706.842 \\
\hline 6 & STORY4 & 18464.296 & 939810.992 & 1260.555 & 3967.397 \\
\hline 7 & STORY3 & 13432.973 & 379613.501 & 509.170 & 4476.567 \\
\hline 8 & STORY2 & 11353.842 & 117345.592 & 157.394 & 4633.961 \\
\hline
\end{tabular}

Tabel 7. Perhitungan distribusi horizontal gaya gempa dan distribusi horizontal arah $Y$ EQUIVALENT LATERAL FORCE (STATIC ANALYSIS)

\begin{tabular}{|c|c|c|c|c|c|}
\hline \multicolumn{6}{|c|}{ EQUIVALENT LATERAL FORCE (STATIC ANALYSIS) } \\
\hline \multirow{2}{*}{ No. } & \multirow{2}{*}{ Story } & $\begin{array}{c}\text { Story } \\
\text { Weight, } \\
\text { Wi }\end{array}$ & WiHlik & Fy Static & $\begin{array}{c}\text { VSTATIC } \\
\text { (VELF) }\end{array}$ \\
\cline { 3 - 6 } & & [tonf] & [tonf] & & [tonf] \\
\hline 1 & STORYROOF & 1853.369 & 308107.810 & 401.257 & 401.257 \\
\hline 2 & STORY8 & 3006.590 & 422132.940 & 549.755 & 951.013 \\
\hline 3 & STORY7 & 3622.273 & 420141.137 & 547.084 & 1498.097 \\
\hline 4 & STORY6 & 5820.584 & 541915.651 & 705.652 & 2203.748 \\
\hline 5 & STORY5 & 5567.823 & 400199.339 & 521.117 & 2724.865 \\
\hline 6 & STORY4 & 18464.296 & 968946.444 & 1261.707 & 3986.571 \\
\hline 7 & STORY3 & 13432.973 & 389597.041 & 507.311 & 4493.882 \\
\hline 8 & STORY2 & 11353.842 & 119494.239 & 155.599 & 4649.481 \\
\hline
\end{tabular}


Untuk memudahkan interpretasi secara visual, berikut ini merupakan tampilan diagram distribusi gaya geser model struktur universitas berdasarkan gaya lateral statik ekivalen SNI 1726:2012

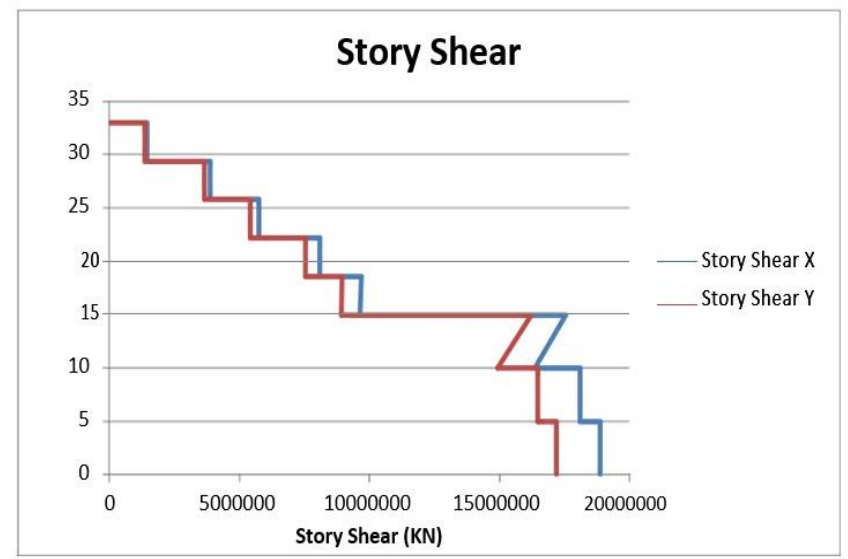

Gambar 8. Gaya geser tingkat berdasarkan gaya lateral static ekivalen

\section{Pola Ragam Getar}

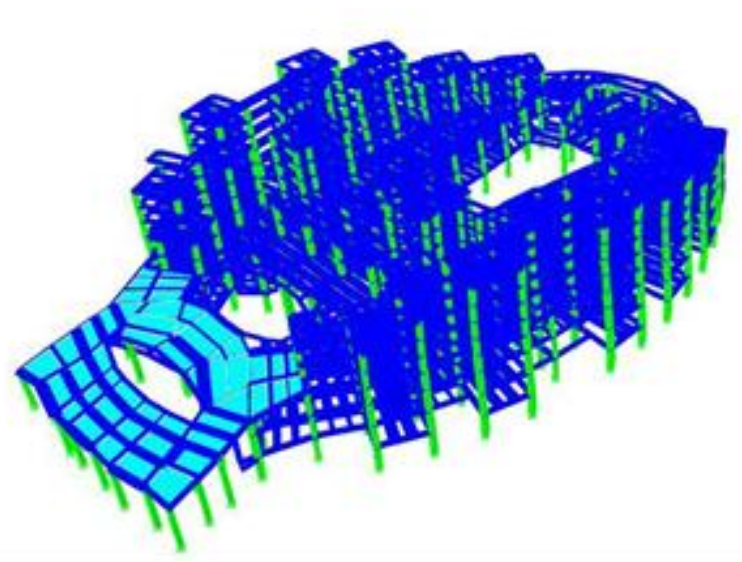

Gambar 9. Pola ragam getar mode pertama transalasi arah $\mathrm{Y}$ dengan periode 1,4248

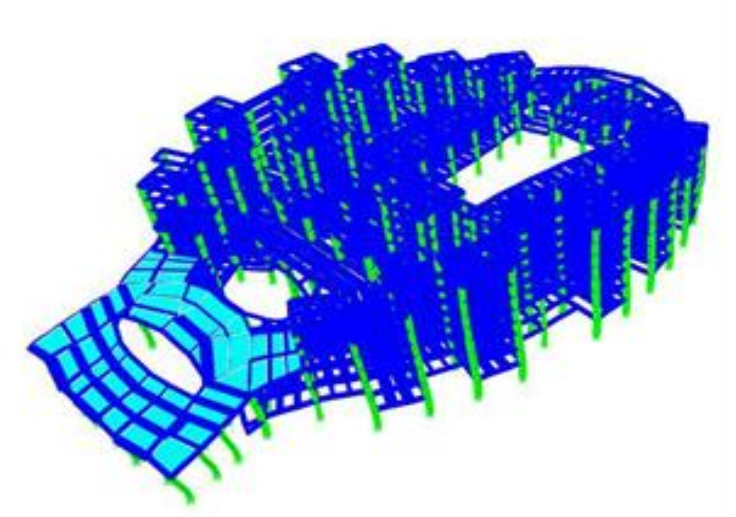

Gambar 10. Pola ragam getar mode kedua transalasi arah $\mathrm{X}$ dengan periode 1,4023

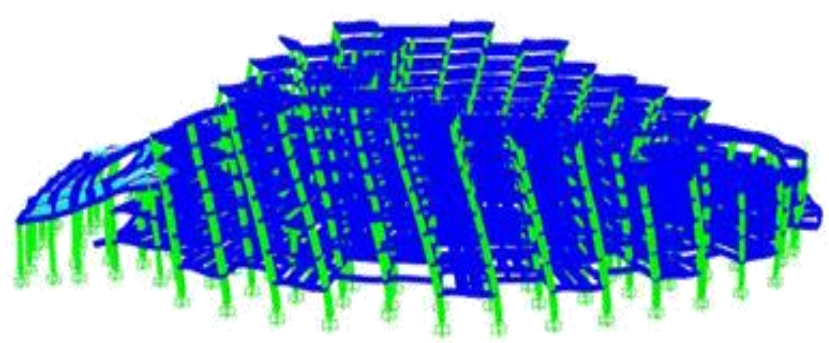

Gambar 11. Pola ragam getar mode ketiga translasi arah rotasi

Masih dilanjutkan oleh Lipke dan Henderson (2006), terlepas dari semua pencapaian dari EV dalam menganalisa kinerja biaya, EV tidak begitu sukses dalam menganalisa kinerja waktu. Pendapat lain dikemukakan oleh Vanhoucke dan Vandevoorde (2007), yang menyatakan bahwa meski EV memiliki sistem yang mampu melacak biaya dan waktu di sepanjang pelaksanaan proyek, mayoritas studi hanya terfokus pada aspek biaya saja. Selanjutnya Velde (2007) menyatakan bahwa EV tidak begitu sukses dalam menilai kinerja waktu, karena kinerja waktu diekspresikan dalam satuan biaya, ketimbang satuan waktu, hal ini menyebabkan hasil pengukuran menjadi tidak valid. Dijelaskan oleh Lipke (2003), setelah proyek selesai 2/3 bagian, kinerja waktu yang dihasilkan oleh EV menjadi tidak dapat "dipercaya". Fenomena ini akan dijelaskan lebih lanjut pada bagian berikut.

Lipke di tahun 2003 telah merumuskan keterbatasan EV dan mengajukan sebuah konsep yang dikenal dengan nama Earn Schedule (ES) untuk mengatasi masalah terkait EV. ES adalah konsep yang baru, yang juga telah divalidasi secara informal oleh Henderson (2003) dan diteliti oleh Vandevoorde dan Vanhoucke (2006), dalam Tzaveas dan Katsavounis, 2011. Metode ES dalam berbagai aplikasinya memberikan hasil yang lebih baik ketimbang metode lain berbasis EV dalam menghasilkan kinerja waktu.

Di Indonesia, penelitian terkait metode EV (metode Nilai Hasil dalam bahasa Indonesia) difokuskan pada aplikasi metode tersebut pada berbagai studi kasus. Sedangkan dalam praktiknya di proyek-proyek konstruksi, metode EV hanya digunakan oleh kontraktor-kontraktor besar. Di sisi lain, penelitian terkait metode ES masih sangat jarang, dan sama dengan metode EV, penelitian hanya difokuskan pada aplikasi metode pada studi kasus.

Penelitian ini bertujuan untuk mengkaji kapabilitas metode ES dalam menilai kinerja waktu dari pelaksanaan proyek dengan efektif. Penelitian ini diharapkan dapat memberikan manfaat dengan menjadi salah satu referensi untuk semakin 


\section{Modal Participating Mass Ratio}

Tabel 8. Periode Numerik dan (MPMR) berdasarkan SNI 1726:2012

\begin{tabular}{|c|c|c|c|c|c|c|c|}
\hline \multicolumn{8}{|c|}{ MODAL PARTICIPATING MASS RATIO } \\
\hline Mode & Period & UX & UY & RZ & SumRX & SumRY & SumRZ \\
\hline 1 & 1.424887 & 0.0001 & 75.302 & 0.0063 & 98.4593 & 0.0002 & 0.0063 \\
\hline 2 & 1.402339 & 78.1953 & 0.0002 & 0.0013 & 98.4595 & 99.4095 & 0.0077 \\
\hline 3 & 1.22842 & 0.0001 & 0.239 & 69.4376 & 98.9771 & 99.4097 & 69.4453 \\
\hline 4 & 0.820701 & 0.2025 & 0 & 0 & 98.9771 & 99.4308 & 69.4454 \\
\hline 5 & 0.771398 & 0.0001 & 2.516 & 3.1719 & 99.2253 & 99.4308 & 72.6172 \\
\hline 6 & 0.69896 & 0.0008 & 5.9127 & 0.0027 & 99.3635 & 99.4308 & 72.62 \\
\hline 7 & 0.686828 & 0.4138 & 0.0033 & 0.0012 & 99.3636 & 99.4336 & 72.6212 \\
\hline 8 & 0.624852 & 1.4437 & 0.2705 & 10.6507 & 99.3831 & 99.4363 & 83.2719 \\
\hline 10 & 0.584633 & 0.0996 & 0.0001 & 0.0008 & 99.3875 & 99.4526 & 85.1032 \\
\hline 11 & 0.549447 & 0.0005 & 3.5213 & 0.2047 & 99.398 & 99.4526 & 85.3078 \\
\hline 12 & 0.52441 & 0.1335 & 0.0013 & 0.0017 & 99.398 & 99.4555 & 85.3095 \\
\hline 13 & 0.493498 & 0.0001 & 1.0064 & 1.4017 & 99.4174 & 99.4555 & 86.7112 \\
\hline 14 & 0.4325 & 0 & 0.0805 & 0.0293 & 99.5841 & 99.4555 & 86.7405 \\
\hline 15 & 0.426892 & 0.1001 & 0.0001 & 0.0001 & 99.5842 & 99.4645 & 86.7405 \\
\hline 16 & 0.382807 & 0.0098 & 0.003 & 0.0618 & 99.5861 & 99.4699 & 86.8023 \\
\hline 17 & 0.381118 & 0.0016 & 0.0225 & 0.3905 & 99.5979 & 99.4709 & 87.1928 \\
\hline 20 & 0.322617 & 0.009 & 0.1445 & 1.6913 & 99.6134 & 99.4719 & 90.3368 \\
\hline 21 & 0.319339 & 2.3076 & 0 & 0.0224 & 99.6134 & 99.5821 & 90.3593 \\
\hline 22 & 0.312317 & 0.0017 & 1.116 & 0.1825 & 99.6556 & 99.5822 & 90.5418 \\
\hline
\end{tabular}

Berdasarkan tabel di atas dapat diketahui bahwa struktur gedung untuk mode pertama pada periode 1,4248 mengalami translasi ke arah $X$, mode kedua pada periode 1,4023 mengalami translasi ke arah $Y$, dan pada mode ketiga mengalami rotasi. Selain itu terlihat bahwa $90 \%$ massa baru tercakup dalam 1 modes pertama untuk arah- $X$ dan 2 modes pertama untuk arah-Y dan 20 modes untuk

\section{Story Shear}

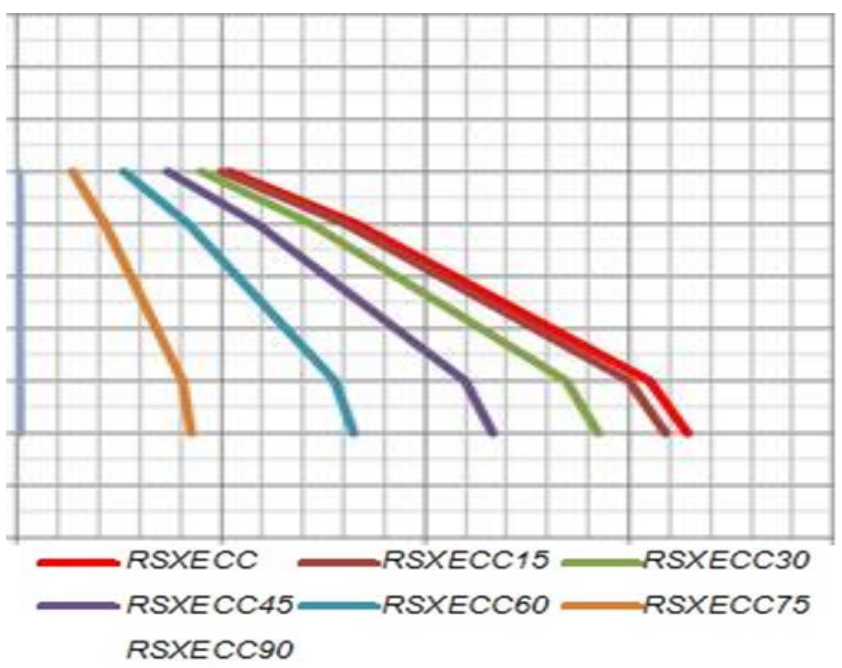

Gambar 12. Perbandingan Story Shear Arah X

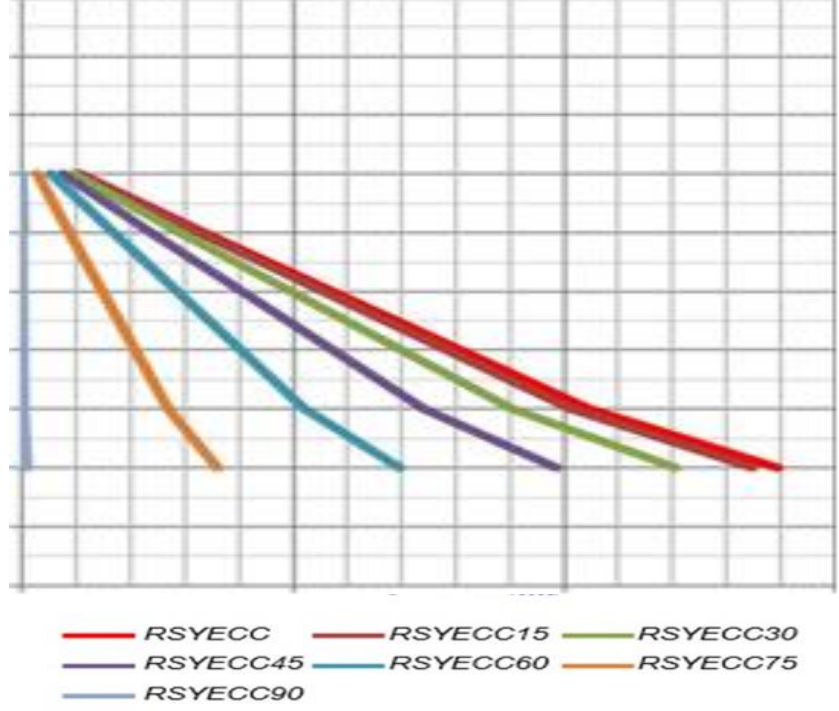

Gambar 13. Perbandingan Story Shear Arah Y

\section{Story Drift}

\begin{tabular}{|c|c|c|c|c|c|c|c|}
\hline \multirow{3}{*}{ Story } & \multirow{2}{*}{$\begin{array}{c}\begin{array}{c}\text { Story } \\
\text { Height }\end{array} \\
\mathrm{h}\end{array}$} & \multicolumn{2}{|c|}{ Story Drift Ratio } & \multicolumn{2}{|c|}{ Design Story Drift } & \multirow{2}{*}{$\begin{array}{c}\begin{array}{c}\text { Allowable } \\
\text { Story } \\
\text { Drift }\end{array} \\
\Delta \mathbf{a}\end{array}$} & \multirow{2}{*}{$\begin{array}{l}\begin{array}{r}\text { Stor } \\
\text { drif } \\
\text { chec }\end{array} \\
\begin{array}{l}\text { X- } \\
\text { dir }\end{array}\end{array}$} \\
\hline & & X-dir & Y-dir & $\Delta \mathbf{x}$ & $\Delta y$ & & \\
\hline & (m) & (m) & (m) & $(\mathrm{mm})$ & $(\mathrm{mm})$ & $(\mathrm{mm})$ & \\
\hline STORYROOF & 3.6 & 0.005187 & 0.005728 & 18.6732 & 20.6208 & 36 & OK \\
\hline STORY8 & 3.6 & 0.006964 & 0.007375 & 25.0704 & 26.55 & 36 & OK \\
\hline STORY7 & 3.6 & 0.008249 & 0.008994 & 29.6964 & 32.3784 & 36 & OK \\
\hline STORY6 & 3.6 & 0.009237 & 0.009501 & 33.2532 & 34.2036 & 36 & OK \\
\hline STORY5 & 3.6 & 0.009069 & 0.009201 & 32.6484 & 33.1236 & 36 & OK \\
\hline STORY4 & 5 & 0.00887 & 0.009367 & 44.35 & 46.835 & 50 & OK \\
\hline STORY3 & 5 & 0.00945 & 0.009588 & 47.25 & 47.94 & 50 & OK \\
\hline STORY2 & 5 & 0.005567 & 0.005605 & 27.835 & 28.025 & 50 & $\mathrm{OK}$ \\
\hline
\end{tabular}




\section{Analisis Ketidakberaturan}

Tabel 9. Simpulan Ketidakberaturan Horizontal

\begin{tabular}{|c|c|c|c|}
\hline \multicolumn{4}{|c|}{ Simpulan Ketidakberaturan Horizontal } \\
\hline \multicolumn{2}{|c|}{ Ketidakberaturan Horizontal } & \multirow{2}{*}{$\frac{\text { Cek }}{\sqrt{ }}$} & \multirow{2}{*}{\begin{tabular}{l}
\multicolumn{1}{c}{$\begin{array}{c}\text { Pasal Referensi SNI } \\
\text { 1726:2012 }\end{array}$} \\
Pasal 7.3.3.4, 7.7.3, \\
7.8.4.3, \\
7.12.1, Tabel 13, 12.2.2 \\
\end{tabular}} \\
\hline $1 \mathrm{a}$ & Ketidakberaturan Torsi & & \\
\hline $1 b$ & $\begin{array}{c}\text { Ketidakberaturan Torsi } \\
\text { Berlebihan }\end{array}$ & - & No Need \\
\hline 2 & $\begin{array}{c}\text { Ketidakberaturan Sudut } \\
\text { Dalam }\end{array}$ & $\sqrt{ }$ & Pasal 7.3.3.4, Tabel 13 \\
\hline 3 & $\begin{array}{c}\text { Ketidakberaturan } \\
\text { Diskontinuitas Diafragma }\end{array}$ & - & No Need \\
\hline 4 & $\begin{array}{l}\text { Ketidakberaturan } \\
\text { Pergeseran Melintang } \\
\text { Terhadap Bidang }\end{array}$ & $\sqrt{ }$ & $\begin{array}{l}\text { Pasal 7.3.3.4, } \\
\text { 7.3.1, } \\
\text { Tabel 13, 12.2.2 }\end{array}$ \\
\hline 5 & $\begin{array}{c}\text { Ketidakberaturan Sistem } \\
\text { Nonparalel }\end{array}$ & - & No Need \\
\hline
\end{tabular}

\section{Level Kinerja Stuktur}

Tabel 10. Batasan Ratio Drift Atap ATC 40

\begin{tabular}{|c|c|c|c|c|}
\hline \multirow{2}{*}{ Parameter } & 10 & $\begin{array}{c}\text { Damage } \\
\text { Control }\end{array}$ & LS & $\begin{array}{c}\text { Structural } \\
\text { Stability }\end{array}$ \\
\cline { 2 - 5 } & 0,01 & $\begin{array}{c}0,01 \mathrm{s.d} \\
0,02\end{array}$ & 0,02 & 0,33 \\
\hline $\begin{array}{c}\text { Maksimum } \\
\text { Total Drift }\end{array}$ & 0,005 & $\begin{array}{c}0,005 \mathrm{~s} . \mathrm{d} \\
0,015\end{array}$ & No Limit & No limit \\
\hline $\begin{array}{c}\text { Maksimum } \\
\text { Total } \\
\text { Inelastik } \\
\text { Drift }\end{array}$ & & & & \\
\hline
\end{tabular}

Persamaan yang digunakan :

Maksimal Drift $=\frac{D t}{H \text { total }}$

Maksimal In-elastic Drift $=\frac{D t-D 1}{H \text { total }} \mathrm{S}$

Keterangan :

$\mathrm{Dt}=$ displacement atap (paling atas)

$\mathrm{D} 1$ = displacement lantai 1 (lantai diatas penjepitan lateral)

\section{Evaluasi Kinerja Stuktur Arah X}

Batasan rasio drift atap yang dievaluasi dengan analisis ragam spektrum respons pada gedung, dengan parameter maksimum total drift dan maksimum inelastik drift, maka:

Maksimal Drift $=\frac{0,00519}{33}=0,0001573$
Maksimal In-elastic Drift $=\frac{0,00519-0,00}{33}=0,0001573$

\section{Evaluasi Kinerja Stuktur Arah Y}

Hasil evaluasi level kinerja struktur sesuai Applied Technology Council 40 pada struktur arah $\mathrm{X}$ dan $\mathrm{Y}$, untuk nilai maksimum total drift dan nilai maksimum total inelastik drift pada arah $\mathrm{X}$ maupun $\mathrm{Y}$ termasuk dalam kategori level Immediate Occupancy (IO) yakni struktur bangunan aman, resiko korban jiwa dari kegagalan struktur tidak terlalu berarti, gedung tidak mengalami kerusakan berarti, dan dapat segera difungsikan/beroperasi kembali.

\section{Diagram Interaksi Kolom}

Kapasitas penampang beton bertulang untuk menahan kombinasi gaya aksial dan momen lentur dapat digambarkan dalam suatu bentuk kurva interaksi antara kedua gaya tersebut, disebut diagram interaksi P-M kolom. Dari diagram interaksi kolom dapat menentukan daerah keruntuhan pada kolom. Berikut gambar diagram interaksi P-M kolom

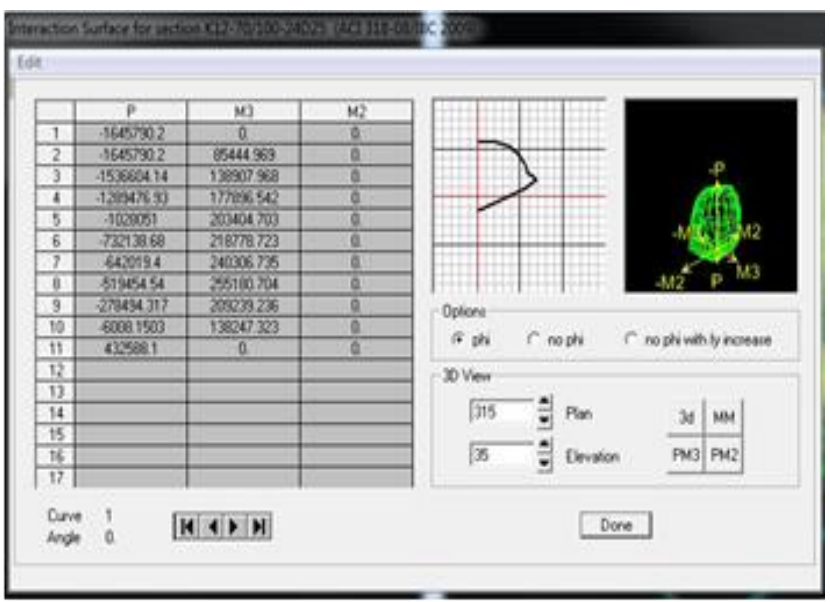

Gambar 14. Diagram Interaksi Kolom Story Roof

\section{Grafik Simpangan Struktur Terhadap Beban Gempa}

Displacement maksimum dan story drift maksimum akibat beban gempa dapat dilihat pada gambargambar di bawah ini:

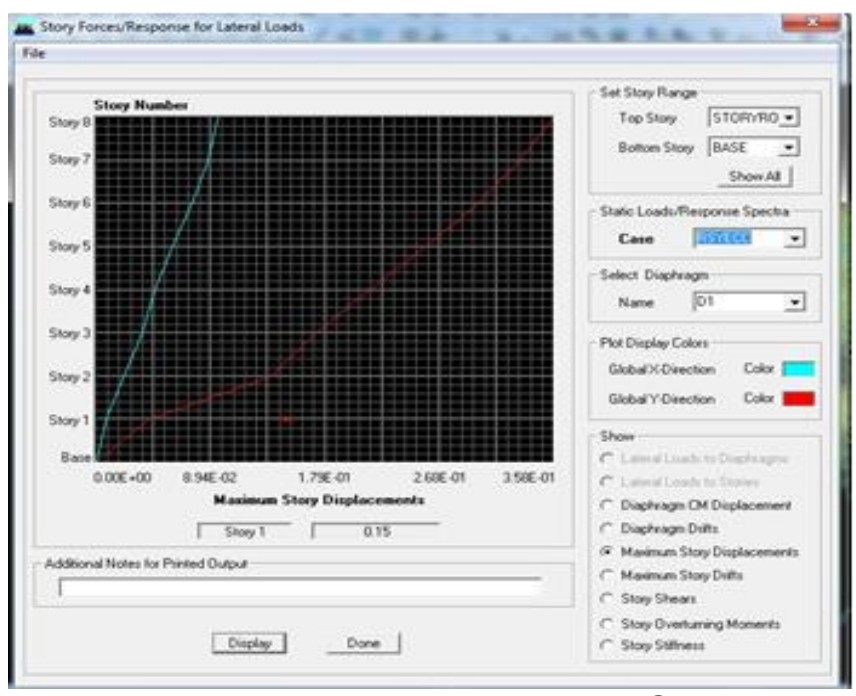

Gambar 15. Displacement Akibat Beban Gempa Arah Y 


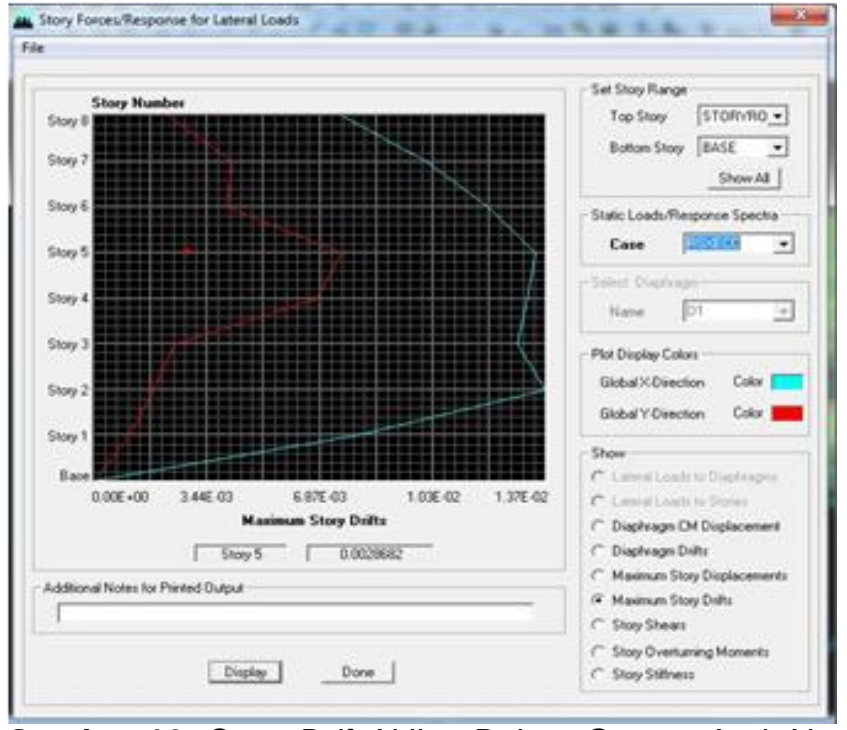

Gambar 16. Story Drift Akibat Beban Gempa Arah X

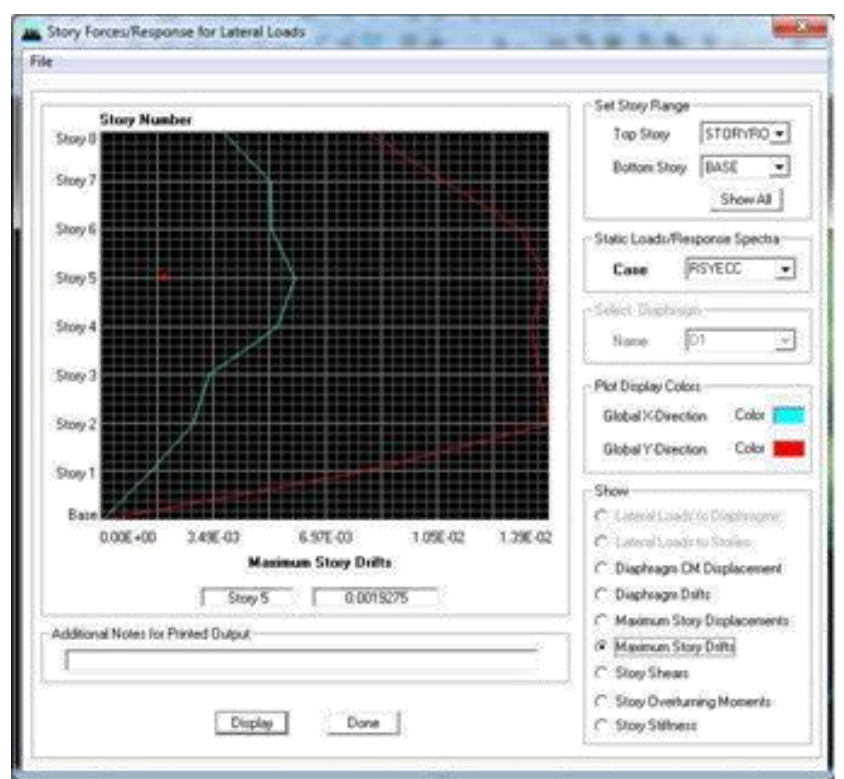

Gambar 17. Story Drift Akibat Beban Gempa Arah Y

\section{KESIMPULAN}

Setelah menganalisis struktur gedung universitas menggunakan metode analisis pushover, maka dapat diambil kesimpulan sebagai berikut :

1. Pada gedung universitas ini terdapat ketidakberaturan torsi, geometri vertical, tingkat lunak berlebih, dan ketidakberaturan massa yang harus di cek dalam pasal referensi pada SNI 1726-2012.

2. Berdasarkan tinjauan displacement pada diafragma kekakuan (D1) arah $\mathrm{X}=0,2956 \mathrm{~m}$ dan arah $Y=0,0327 \mathrm{~m}$, diafragma kekakuan (D1b) arah $X=0,4058 m$ dan arah $Y=0,0372 m$,dan diafragma kekakuan (D1a) arah $X=0,4332 \mathrm{~m}$ dan arah $Y=0,0518 \mathrm{~m}$ gedung universitas dinyatakan aman terhadap syarat evaluasi kinerja batas layan dan batas ultimate sesuai SNI 031726-2012.
3. Berdasarkan hasil analisis ragam spektrum respons terhadap level kinerja struktur sesuai ATC-40, pada arah $X$ maupun arah $Y$ nilai maksimum total drift menunjukan gedung yang dianalisis termasuk dalam kategori level Immediate Occupancy. Nilai maksimum total inelastik drift pada arah $\mathrm{X}$ menunjukan gedung yang dianalisis juga termasuk dalam kategori level Immediate Occupancy.

\section{REFERENSI}

Applied Technology Council, A.-4. R. (1996). Seismic Evaluation and Retrofit of Concrete Building: Volume 1. California.

Badan Standarisasi Nasional. (2013). SNI 1727:2013 : Beban minimum untuk perancangan bangunan gedung dan struktur lain.

Badan Standarsasi Nasional. (2012). SNI 17262012 : Standar Perencanaan Ketahanan Gempa untuk Struktur Bangunan Gedung.

Budiono, B. (2011). Studi Komaparasi Desain Bangunan Tahan Gempa Dengan Menggunakan SNI 03-1726-2002 Dan RSNI 03-1726-201x. Bandung: Penerbit ITB.

Budiono, B. (2013). Konsep SNI Gempa 17262012. Jakarta.

Dya, A. F., \& C. Oretaa, A. W. (2015). Seismic vulnerability assessment of soft story irregular buildings using pushover analysis.

FederalEmergency Management Agency (FEMA). (2007). NEHRP Recommended Provisions for Seismic Regulations for New Buildings and Other Structures (FEMA 451B).

Fransisca, D. M. (2016). Studi Performa Struktur Gedung Bertingkat Ketidakberaturan Torsi Berdasarkan Perencanaan Urutan Sendi Plastis Dengan Pushover Analysis.

Marwanto, A., Budi, A. S., \& Supriyadi, A. (2014, September). Evaluasi Kinerja Struktur Gedung 10 Lantai Dengan Analisis Pushover Terhadap Drift Dan Displacement Menggunakan Software Etabs ( Studi Kasus : Hotel Di Wilayah Surakarta ).

Nasional, B. S. (2013). SNI 2847-2013: Persyaratan Beton Struktural untuk Bangunan Gedung.

Nugroho, F. (2016, Agustus). Penerapan Analisis Pushover Untukmenentukan Kinerja Struktur Padabangunan Eksisting Gedung Beton Bertulang.

Palupi, A. S. (2015). Studi Kinerja Struktur gedung Supermall Pakuwon Mansion Phase-1 Surabaya Menggunakan Metode Analisa Pushover.

Piranti, S. N. (2015). Perilaku Struktur Bangunan Yang Memiliki Ketidakberaturan Massa Terhadap Beban Gempa Kuat Berdasarkan Rsni 03-1726-201x.

Rachman, N. Z., Purwanto, E., \& Suptiyadi, A. (2014, Desember). Analisis Kinerja Struktur Pada Gedung Bertingkat Dengan Analisis Pushover Menggunakan Software Etabs 
(Studi Kasus : Bangunan Hotel Di Semarang).

T. G., \& P. A. (2012). Seismic evaluation of multistorey moment-resisting steel frames with pushover.

Wibowo, E. P., \& D. Y. (2010). Menentukan Level Kinerja Struktur Beton Bertulang Pasca Gempa.

Wicaksono, P. A. (2015). Perilaku Struktur Bangunan Dengan Ketidakberaturan Geometri Vertikal Terhadap Beban Gempa Kuat Berdasarkan 
Halaman ini sengaja dikosongkan 